\title{
The prevalence of MS in the United States
}

\section{A population-based estimate using health claims data}

\begin{abstract}
Mitchell T. Wallin, MD, MPH, William J. Culpepper, PhD, Jonathan D. Campbell, PhD, Lorene M. Nelson, PhD, Annette Langer-Gould, MD, PhD, Ruth Ann Marrie, MD, PhD, Gary R. Cutter, PhD, Wendy E. Kaye, PhD, Laurie Wagner, MPH, Helen Tremlett, PhD, Stephen L. Buka, ScD, Piyameth Dilokthornsakul, PharmD, PhD, Barbara Topol, MS, Lie H. Chen, DrPH, and Nicholas G. LaRocca, PhD, on behalf of the US Multiple Sclerosis Prevalence Workgroup
\end{abstract}

Neurology ${ }^{\circledR}$ 2019;92:e1029-e1040. doi:10.1212/WNL.0000000000007035

\section{Abstract}

\section{Objective}

To generate a national multiple sclerosis (MS) prevalence estimate for the United States by applying a validated algorithm to multiple administrative health claims (AHC) datasets.

\section{Methods}

A validated algorithm was applied to private, military, and public AHC datasets to identify adult cases of MS between 2008 and 2010. In each dataset, we determined the 3-year cumulative prevalence overall and stratified by age, sex, and census region. We applied insurance-specific and stratum-specific estimates to the 2010 US Census data and pooled the findings to calculate the 2010 prevalence of MS in the United States cumulated over 3 years. We also estimated the 2010 prevalence cumulated over 10 years using 2 models and extrapolated our estimate to 2017.

\section{Results}

The estimated 2010 prevalence of MS in the US adult population cumulated over 10 years was 309.2 per 100,000 (95\% confidence interval [CI] 308.1-310.1), representing 727,344 cases. During the same time period, the MS prevalence was 450.1 per 100,000 (95\% CI 448.1-451.6) for women and 159.7 (95\% CI 158.7-160.6) for men (female:male ratio 2.8). The estimated 2010 prevalence of MS was highest in the 55- to 64-year age group. A US north-south decreasing prevalence gradient was identified. The estimated MS prevalence is also presented for 2017.

\section{Conclusion}

The estimated US national MS prevalence for 2010 is the highest reported to date and provides evidence that the north-south gradient persists. Our rigorous algorithm-based approach to estimating prevalence is efficient and has the potential to be used for other chronic neurologic conditions.

\author{
Correspondence \\ Dr. Wallin \\ mitchell.wallin@va.gov
}

\section{Article}

Validation of an algorithm for identifying MS cases in administrative health claims datasets

Page e1016

\section{Views and Reviews}

A new way to estimate neurologic disease prevalence in the United States: Illustrated with MS Page 469

\section{MORE ONLINE}

\section{ค Podcast}

Dr. Stacey Clardy talks with Dr. Mitchell Wallin about his paper on the prevalence of MS in the United States. NPub.org/bsqqt1 


\section{Glossary}

AHC $=$ administrative health claims; $\mathbf{C I}=$ confidence interval; $\mathbf{I C D}-9$ = International Classification of Disease-9th revision; KPSC $=$ Kaiser Permanente Southern California; MEPS = Medical Expenditure Panel Survey; MS = multiple sclerosis; NMSS = National Multiple Sclerosis Society; OP = Optum; TH = Truven Health; VA = Department of Veterans Affairs.

Chronic disease morbidity is challenging to assess within the United States because it lacks a unified health system, and limited infrastructure exists for identifying and tracking patients across their lifespan. Options for determining incidence and prevalence estimates include surveys, registries, or administrative health claims (AHC) datasets. Each method has strengths and limitations; however, the increasing availability of large AHC datasets has made this approach efficient and cost-effective. ${ }^{1}$

Multiple sclerosis (MS) is the most common progressive neurologic disease of young adults worldwide. ${ }^{2,3}$ Current estimates suggest that 300,000 to 400,000 individuals are affected in the United States, but this is based largely on revisions of estimates from older data. ${ }^{2-6}$ These estimates do not reflect the changing demographics of the United States or potential changes in the ascertainment of MS due to modifications in the diagnostic criteria and new treatment options. Moreover, studies in neighboring Canada have reported steep increases in the prevalence of MS over the past few decades across several provinces. ${ }^{7-9}$

Because of the challenges in estimating MS prevalence for the United States, the National Multiple Sclerosis Society (NMSS) formed the Multiple Sclerosis Prevalence Workgroup, made up of scientists and policy advocates with the goal of producing a scientifically sound and economically feasible national MS prevalence estimate. By applying a validated case algorithm for MS to multiple large AHC datasets, we aimed to generate a robust national MS prevalence estimate for the adult population, stratified by age, sex, and region.

\section{Methods}

\section{Setting and data sources}

The United States includes 48 contiguous states, Hawaii, and Alaska. The 48 contiguous states range from $\approx 24.52^{\circ} \mathrm{N}$ to $49.28^{\circ} \mathrm{N}$ latitude and from $\approx 66.95^{\circ} \mathrm{W}$ to $124.77^{\circ} \mathrm{W}$ longitude. The US population encompassing all 50 states is steadily growing, having increased from 309.3 million in 2010 to 325.8 million in $2017 .{ }^{10}$ In the United States, health insurance may be obtained from several private or public (government) sources, and a proportion of the population is uninsured. We acquired several AHC datasets representing the US private and government-sponsored insurance programs, reasoning that nearly all persons with MS, except the uninsured, Native Americans using the Indian Health Service, and the incarcerated, would receive health services through one of these programs. Each included the adult population ( $\geq 18$ years) and their health care use for the years 2008 to 2010. The breakdown of the population within specific health insurance programs varies by income, sex, disability, and age group. ${ }^{1}$

\section{Private insurance}

In 2016, most adults $<65$ years of age $(73 \%)$ obtained their health care coverage from private insurance plans. ${ }^{11}$ Because the AHC datasets available for the private insurance sector vary in terms of geographic coverage and the types of providers represented, we accessed 3 datasets: Optum (OP), Truven Health $(\mathrm{TH})$, and Kaiser Permanente Southern California (KPSC). These 3 private health datasets represent a broad sample of all such plans in the US insurance market. Two of these datasets (OP and TH for 2008-2010) were used in the prevalence calculations and collectively capture $\approx 35 \%$ of the privately insured in the United States.

\section{Public insurance}

Low-income adults and those with particular disabilities may obtain health care coverage through government-funded Medicaid plans. In 2016, $96 \%$ of US adults $\geq 65$ years of age were enrolled in government-funded Medicare. ${ }^{11}$ In the public sector, the Centers for Medicare \& Medicaid Services datasets captured all eligible persons (100\%) enrolled in Medicare or Medicaid across the United States ( $>50$ million individuals). ${ }^{12}$ All active-duty military enrollees receive their health care from the Department of Defense, and based on current eligibility criteria, $\approx 30 \%$ to $40 \%$ transfer to the Department of Veterans Affairs (VA) health care and benefit system when they leave active duty. To assess the military sector, we used the VA database, which included all persons enrolled in the VA health care system. Collectively, these datasets provided health care information for $>125$ million persons.

The AHC datasets varied with respect to the information captured. Therefore, we developed a common data dictionary and variable list for this study. These included a denominator file for all enrollees, including dates of insurance eligibility, sex, year of birth, and geographic region of residence. Because race and ethnicity were not available in all data sources, they were not considered in this analysis. We also accessed data on health care encounters in the inpatient and outpatient settings, as well as prescription drug claims. Each inpatient and outpatient encounter included $\geq 1$ diagnostic codes, recorded with the ICD-9 system, as well as the date of the encounter. In the ICD-9 system, MS is uniquely identified by the 340 code. For inpatient encounters, we used the date of admission. Prescription drug claims included the name of the medication and the date of release. 


\section{Diagnostic algorithm for MS}

As described elsewhere, ${ }^{13}$ we developed and tested several algorithms to identify people with MS using AHC datasets compared with physician-adjudicated MS cases as the reference standard. The optimal algorithm in terms of sensitivity, specificity, and simplicity required the accumulation of $\geq 3$ MS-related hospitalizations, outpatient visits, or prescription release encounters for an MS disease-modifying therapy in any combination within a 1-year period. For prescription drug claims, we considered only diseasemodifying therapies approved by the US Food and Drug Administration for MS by 2010, including the interferon betas, glatiramer acetate, natalizumab, and fingolimod. ${ }^{14}$ To avoid misclassification, claims for natalizumab were not included if the individual also had an ICD-9 code for inflammatory bowel disease, another disorder for which this medication is approved.

When tested among individuals with at least 1 MS claim, the sensitivity of the MS algorithm was $86 \%$ to $92 \%$ and the specificity was $66 \%$ to $83 \%$, depending on the dataset. ${ }^{13}$ When tested in a Canadian population that included individuals with and without any MS claims (i.e., general population), the sensitivity was $96.0 \%$ and the specificity was $99.5 \%{ }^{13}$

\section{Prevalence estimates}

For the TH, OP, VA, and KPSC datasets, enrollees who also had Medicare coverage were removed from both the numerators and the denominators within each dataset to prevent double counting. The annual prevalence within a given dataset was demarcated as all those who met the MS case definition divided by the annual population at risk, defined as all enrollees $\geq 18$ years of age at the beginning of the calendar year and with health plan eligibility for a total of 6 months within the calendar year. Because individuals with MS may have variable contact with the health system, once an enrollee met the case definition and remained eligible for care, he or she was considered a case thereafter. Applying the algorithm to each dataset, we determined the prevalence at the end of the 3-year study period by identifying all persons who met the case definition in any 1 of the 3 study years who were still alive and eligible for care in the last year of the study period (2010) and dividing this by the population at risk in 2010. These 3-year prevalence estimates were stratified by sex, age (18-24, 25-34, 35-44, 45-54, 55-64, 67-74, and $\geq 75$ years) and US Census region (North, East, South, and West). They were directly age and sex standardized to the 2010 US Census. ${ }^{10}$ Confidence intervals (CIs) were calculated for the final total number of cases using binomial CIs $( \pm 1.96 \times$ $\sqrt{ }(\mathrm{NPQ}$, where $\mathrm{P}$ and $\mathrm{Q}$ are the proportions of cases and noncases and $\mathrm{N}$ is the estimated US population in 2010). The 95\% CIs were then adjusted for the rate per 100,000, and the inflation factors were calculated with a fixed-effects model. Verification of the prevalence estimates was performed for each dataset by 2 independent reviewers (W.E.K. and L.W.) for quality control.
To obtain a national US prevalence estimate for MS, we undertook several analytic steps. First, we treated estimates from $\mathrm{OP}$ and $\mathrm{TH}$ as random samples drawn from the same underlying population (the commercially insured), so their ageand sex-stratified estimates were pooled with the use of a random-effects model to represent the US private insurance populations. Because KPSC was included in the general population denominator in the West region, it was not included in these calculations. Sensitivity analyses examining the effects of including or excluding KPSC from the West region were conducted, and the findings did not differ significantly (data not shown). Second, we used data from the US Census to determine the total size of the US population in each age and sex stratum and the proportion with private, public, and military health insurance coverage. ${ }^{15}$ Medicaid, Medicare, and military veteran prevalence estimates fully captured these populations. ${ }^{10,15}$ The stratum-specific estimate was multiplied by the total insured US population in that stratum to determine the number of individuals affected. In $2010,16 \%$ of the US population was uninsured, but the proportion uninsured varies across conditions. ${ }^{11,16}$ To account for the uninsured MS population, we used data from both the Sonya Slifka cohort study ${ }^{17}$ and the NMSS, which reported a $5.0 \%$ uninsured rate within the MS population before the initiation of the Affordable Care Act. Thus, the number of individuals affected in each stratum was summed, inflated by $5.0 \%$ to account for the uninsured across all strata, and then divided by the total US population to generate a summary prevalence estimate for the United States.

The term cumulative prevalence applies to our case finding approach within datasets in that once an individual meets the MS case definition for a given year, that person is counted as a case for subsequent years through 2010 if he or she remains active in the health plan. This method of case ascertainment effectively represents a limited-duration (3-year) prevalence. Ultimately, the prevalence estimate of interest is lifetime prevalence, which is the proportion of a population that at some point in life (up to the time of assessment) has developed MS. In chronic, predominantly relapsing diseases such as MS that start in early adult life, individuals may forgo contact with the health system for extended periods. Thus, long periods of observation (minimum 10 years) are needed to approach lifetime prevalence in the assessment of AHC datasets, as described previously for systemic lupus erythematosus ${ }^{18}$ and as widely recognized in the cancer literature. ${ }^{19}$ As noted elsewhere, ${ }^{13}$ by using AHC datasets available from Intercontinental Marketing Services, the VA, and the province of Manitoba over the period of 2000 to 2016, we determined the proportion of cases missed by using a 3-year vs 10-year cumulative prevalence estimate. On the basis of these findings, undercount adjustment factors for the 10-year cumulative prevalence were required and were estimated to range from 1.37 (lower bound, 95\% CI 1.13-1.66) to 1.47 (upper bound, 95\% CI 1.23-1.76). We applied these factors to derive estimates for the 2010 prevalence of MS cumulated over 10 years. ${ }^{13}$ 


\section{Complementary analysis}

The cumulative prevalence of MS grows at variable rates and eventually levels off when an algorithm is applied to a given health system AHC dataset. ${ }^{7,13}$ We have shown that the average annual growth in the MS prevalence rate between 2010 and 2017 for $2 \mathrm{AHC}$ datasets was $2.3 \% / \mathrm{y}{ }^{13}$ This growth rate can be applied to the 2010 prevalence estimates to obtain a more recent prevalence figure.

SAS version 9.4 (SAS Institute Inc, Cary, NC) and SPSS version 22 (IBM Inc, Armonk, NY) were used to conduct the statistical analyses.

\section{Standard protocol approvals, registrations, and patient consents}

The study was approved by the Institutional Review Board at the VA Medical Center-Baltimore/University of Maryland Medical Center, KPSC, Colorado Multiple Institutional Review Board, Stanford University, and Quorum Review. Standard contracts and data use agreements were obtained for the analysis of all datasets.

\section{Data availability}

The datasets for this study were purchased and are owned by the NMSS. There are no current sharing agreements, and data are held under a data use contract with the NMSS.

\section{Results}

The characteristics of the AHC datasets during the study period are summarized in table 1 ; in total, they captured 125 million persons $\geq 18$ years of age. The 3 private insurance datasets collectively captured 58 million individuals, approximately half of the privately insured US adult population (age 18-64 years). Collectively, the public (government) insurance sources captured all 68 million individuals nationwide who are insured through these plans.

The prevalence estimates reported refer to the adult population. The age- and sex-stratified prevalence estimates for MS in 2010 cumulated over 3 years (2008-2010) and number of cases from these datasets are displayed in tables e-1 through e-5 (available from Dryad, https://doi.org/10.5061/dryad.pm793v8). The prevalences for OP and TH are remarkably similar, while the VA sex-stratified estimates are highest among the datasets. Denominator data from the 2010 US Census are shown in table e- 6 (available from Dryad, https://doi.org/10.5061/dryad.pm793v8).

The annual cumulative prevalence of MS in the United States for 2008 to 2010 using the MS algorithm is displayed for the 2 private health insurance datasets ( $\mathrm{OP}$ and $\mathrm{TH}$ ) and the 3 government insurance datasets (Medicaid, Medicare, and VA) in figure 1 . The average annual increase in prevalence

Table 1 Characteristics of AHC datasets used for the US MS prevalence estimate

\begin{tabular}{|c|c|c|c|c|}
\hline Health claims database (URL) & $\begin{array}{l}\text { Adult enrollees } \\
\text { 2008-2010, } n\end{array}$ & Health plan characteristics & $\begin{array}{l}\text { Geographic } \\
\text { coverage }\end{array}$ & Variables in database \\
\hline OP (optum.com) & 15 million & $\begin{array}{l}\text { Employer-based, fee-for-service, } \\
\text { preferred provider, or capitated } \\
\text { health plans; United Health Care }\end{array}$ & All 50 states & $\begin{array}{l}\text { Demographic data, hospital } \\
\text { admissions, outpatient claims, } \\
\text { emergency room claims, prescription } \\
\text { medications }\end{array}$ \\
\hline $\begin{array}{l}\text { TH Market Scan (marketscan. } \\
\text { truvenhealth.com) }\end{array}$ & 40 million & $\begin{array}{l}\text { Mix of private health insurance } \\
\text { companies }\end{array}$ & All 50 states & $\begin{array}{l}\text { Demographic data, hospital } \\
\text { admissions, outpatient claims, } \\
\text { behavioral health claims, emergency } \\
\text { room claims, prescription } \\
\text { medications }\end{array}$ \\
\hline
\end{tabular}

\begin{tabular}{|c|c|c|c|c|}
\hline $\begin{array}{l}\text { KPSC (share. } \\
\text { kaiserpermanente.org) }\end{array}$ & 2.7 million & $\begin{array}{l}\text { Health maintenance organization } \\
\text { with integrated clinical and hospital } \\
\text { network }\end{array}$ & $\begin{array}{l}\text { Southern } \\
\text { California }\end{array}$ & $\begin{array}{l}\text { Demographic data, hospital } \\
\text { admissions, outpatient claims, } \\
\text { emergency room claims, prescription } \\
\text { medications, clinical records data, } \\
\text { laboratory data, imaging data }\end{array}$ \\
\hline VA (va.gov) & 8.5 million & $\begin{array}{l}\text { National government health care } \\
\text { program for military veterans; } \\
\text { outpatient clinics, medical centers, } \\
\text { rehabilitation facilities, nursing } \\
\text { homes, and service offices }\end{array}$ & All 50 states & $\begin{array}{l}\text { Demographic data, hospital } \\
\text { admissions, outpatient claims, } \\
\text { emergency room claims, prescription } \\
\text { medications, clinical records, } \\
\text { laboratory data, imaging data }\end{array}$ \\
\hline Medicaid (national) (cms.gov) & 27.9 million & $\begin{array}{l}\text { State-based health insurance } \\
\text { program supplemented by federal } \\
\text { funding to provide for those in } \\
\text { poverty or with designated disabilities }\end{array}$ & All 50 states & $\begin{array}{l}\text { Demographic data, hospital } \\
\text { admissions, outpatient claims, } \\
\text { emergency room claims, prescription } \\
\text { medications }\end{array}$ \\
\hline Medicare (national) (cms.gov) & 31.2 million & $\begin{array}{l}\text { Federal health insurance program for } \\
\text { the elderly ( } \geq 65 \mathrm{y} \text { ) and disabled }\end{array}$ & All 50 states & $\begin{array}{l}\text { Demographic data, hospital } \\
\text { admissions, outpatient claims, } \\
\text { emergency room claims, prescription } \\
\text { medications }\end{array}$ \\
\hline
\end{tabular}

Abbreviations: $\mathrm{AHC}=$ administrative health claims; KPSC = Kaiser Permanente Southern California; MS = multiple sclerosis; OP = Optum; TH = Truven Health; VA = Department of Veterans Affairs. 
Figure 1 Average annual prevalence of MS in the United States for 2008, 2009, and 2010 per 100,000 population for private (OP and TH, black lines) and government (Medicaid, Medicare, and VA, red lines) health insurance datasets

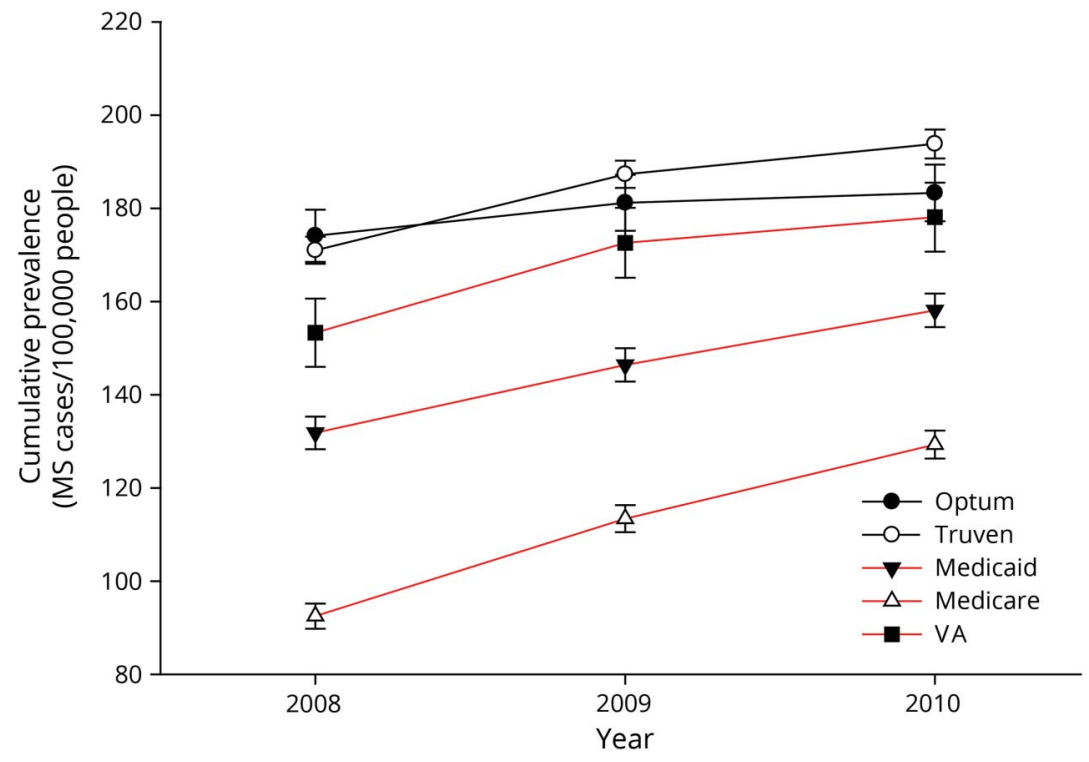

Multiple sclerosis (MS) cases acquired from the MS algorithm in year 1 are displayed, along with new cases added cumulatively in subsequent years. $\mathrm{OP}=$ Optum; $\mathrm{TH}=$ Truven Health; $\mathrm{VA}=$ Department of Veterans Affairs. over this 3-year period for all datasets was 6.3\% (SD 3.8\%). The 2010 MS prevalence estimate cumulated over 3 years for the combined datasets was 199.84 (95\% CI 199.83-199.85), corresponding to 470,053 people with MS.

After adjustment for the uninsured and application of the lower-bound inflation factor to account for undercounting due to the limited period of observation, the estimated 2010 prevalence for MS cumulated over 10 years was 265.1 per 100,000 (95\% CI 264.3-265.8), corresponding to 623,437 people with MS. Similarly, after adjustment for the uninsured and application of the upper-bound inflation factor, the 2010 prevalence for MS cumulated over 10 years was 309.2 per 100,000 (95\% CI 308.1-310.1), representing a total of 727,344 people with MS. The 2010 MS prevalence estimates cumulated over 10 years, $95 \%$ CIs, and number of cases in the United States stratified by age and sex (lower and higher estimates) are shown in table e-7 (available from Dryad, https://doi.org/10.5061/dryad.pm793v8). Figure 2 shows the lower and figure 3 displays the higher $2010 \mathrm{MS}$ prevalence estimates cumulated over 10 years in the United States stratified by age and sex. The overall female:male prevalence ratio for 2010 was 2.8. The peak age-specific MS prevalence was 55 to 64 years, followed by 65 to 74 years.

Tables 2 and 3 show the 2010 MS prevalence estimates cumulated over 10 years, $95 \%$ CIs, and number of cases in the US by age, sex, and geography (lower and higher estimates). Figure 3 illustrates the higher estimate for 2010 cumulated over 10 years by Census regions, along with corresponding sex ratios. The prevalence in the northern Census regions of the US (Northeast and Midwest) was statistically significantly higher than in the southern Census region as evidenced by nonoverlapping 95\% CIs.

\section{Discussion}

We report a current national prevalence estimate for MS in the adult population by using a validated algorithm across 5 large US AHC datasets, which also accounted for the uninsured population and for the limited (3-year period) of observation. Our estimates were based on a case-finding strategy that identified MS cases annually combined with the 2010 Census for denominator data. Overall, nearly $45 \%$ of the US population was assessed, including $100 \%$ of those with publicly funded insurance. In 2010, our higher 10-year prevalence estimate was 309.2 per 100,000 population, representing 727,344 adults affected by MS. This higher 2010 estimate is based on the adjustment (3-year vs 10-year) seen in a single health insurance payer system covering the entire population. The lower-level estimate is based on a dataset adjustment (3-year vs 10-year) for a government insurance carrier for a segment of the population. Our approach accounted for the demographics of the national population, the sporadic follow-up for a chronic disease with young-adult onset, the different insurance providers within the health care system, and the uninsured.

When coupled with prior estimates of the prevalence of MS in the US, our findings suggest that there has been a steady rise in the prevalence of MS over the past 5 decades, that the prevalence of MS remains higher for women than men, and that a north-south geographic gradient still persists. ${ }^{2}$ The earliest published national US MS prevalence estimate for the 

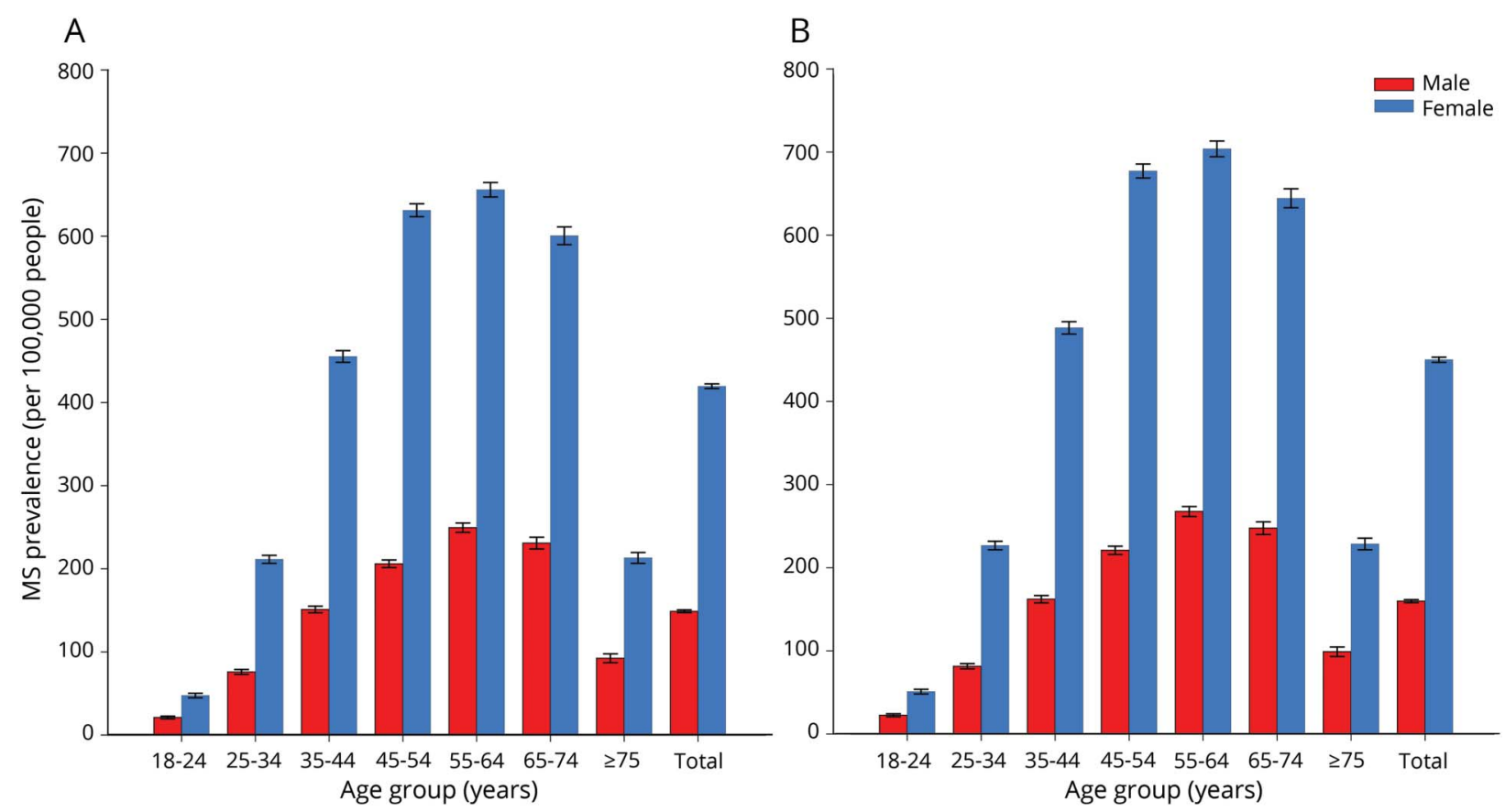

Higher and lower estimates adjusted to 2010 US Census based on combined datasets from the multiple sclerosis (MS) algorithm inclusive of the following: Truven, Optum, Department of Veterans Affairs, Medicare, and Medicaid (full data available for all age and sex estimates in data table e-7 available from Dryad, https://doi.org/10.5061/dryad.pm793v8). (A) Lower-estimate and (B) higher-estimate 2010 MS prevalence in the United States per 100,000 population.

adult and pediatric populations combined was 58 per 100,000 for the year $1976,{ }^{4}$ corresponding to 123,000 cases with a 1.7 female:male ratio. That study used surveys of hospitals, physicians, and patients to estimate prevalence. Subsequent researchers used this prevalence of 58 per 100,000 as a baseline and estimated the number of physician-diagnosed MS cases in the United States as 300,000 by 1990 after factoring in population changes and more contemporary regional prevalence estimates. ${ }^{5}$ Using the National Health Interview Survey, investigators calculated a national MS prevalence rate of 85 per 100,000 for the period of 1989 to $1994 .{ }^{20}$ The corresponding female:male ratio was reported as 2.6:1, much higher than the 1976 sex ratio. ${ }^{4}$ Authors of a later study reported a national annual period prevalence of $0.21 \%$ over a 10-year period (1998-2009), with cases with MS identified by at least 1 ICD-9340 code in the Medical Expenditure Panel Survey (MEPS). ${ }^{21}$ This corresponded to 572,312 patients with MS. More recently, a team with a more restrictive algorithm over 5 years (2008-2012) using the PharMetrics commercially insured claims database produced an annual period MS prevalence estimate of 149 per 100,000 with 403,630 individual cases, ${ }^{22}$ which is reasonably consistent with our 3-year estimate in 2010 of 470,053 cases. The corresponding female:male ratio was 3.1. The higher prevalence estimate of the MEPS database over a longer ascertainment period than that of the PharMetrics study emphasizes the need to account for undercounting with limited observation periods. This also accounts for the fact that our prevalence figure is most in line with the 10-year MEPS database estimate but with the advantage of a formally validated algorithm and a broader demographic sample.

We did not assess the prevalence of MS in children, and this should be considered when our findings are compared to those reported in other populations. If we use our agestratified rates for 2010 (low and high estimates), they fall within the range of the 2006 MS prevalence estimates in Manitoba, Canada, ${ }^{7}$ for all 10-year age groups. Similarly, the age-stratified prevalence estimates for Northern Ireland, United Kingdom, in 2004 were slightly higher than our agespecific estimates for the following age deciles: 25 to 34,25 to 44 , and 45 to 54 years. ${ }^{23}$ MS prevalence in older age groups was slightly higher in the 2010 US population. Compared to the 2008 age-stratified prevalence estimates from British Columbia, Canada, ${ }^{8}$ our US rates were variably higher $(2 \%-30 \%)$ for all age categories. Thus, our age-stratified estimates are in line with recent North American and European figures. If we were to assume that the prevalence of MS in children were zero, although this is a conservative assumption, our 2010 prevalence estimates would range from 218.6 (low estimate) to 234.5 (high estimate) per 100,000 population.

Thus, our prevalence results are consistent with recent reports of MS prevalence from other regions that examined the entire population. Canada has observed dramatic increases in the prevalence of MS, with an estimate of 266.9 per 100,000 in Nova Scotia ${ }^{9}$ for the year 2010 and a prevalence of 179.9 per 
Figure 3 High-estimate 2010 prevalence of MS in the United States per 100,000 population (2010 US Census) by Census region with $95 \% \mathrm{Cl}$ and $\mathrm{F}: \mathrm{M}$ prevalence ratio

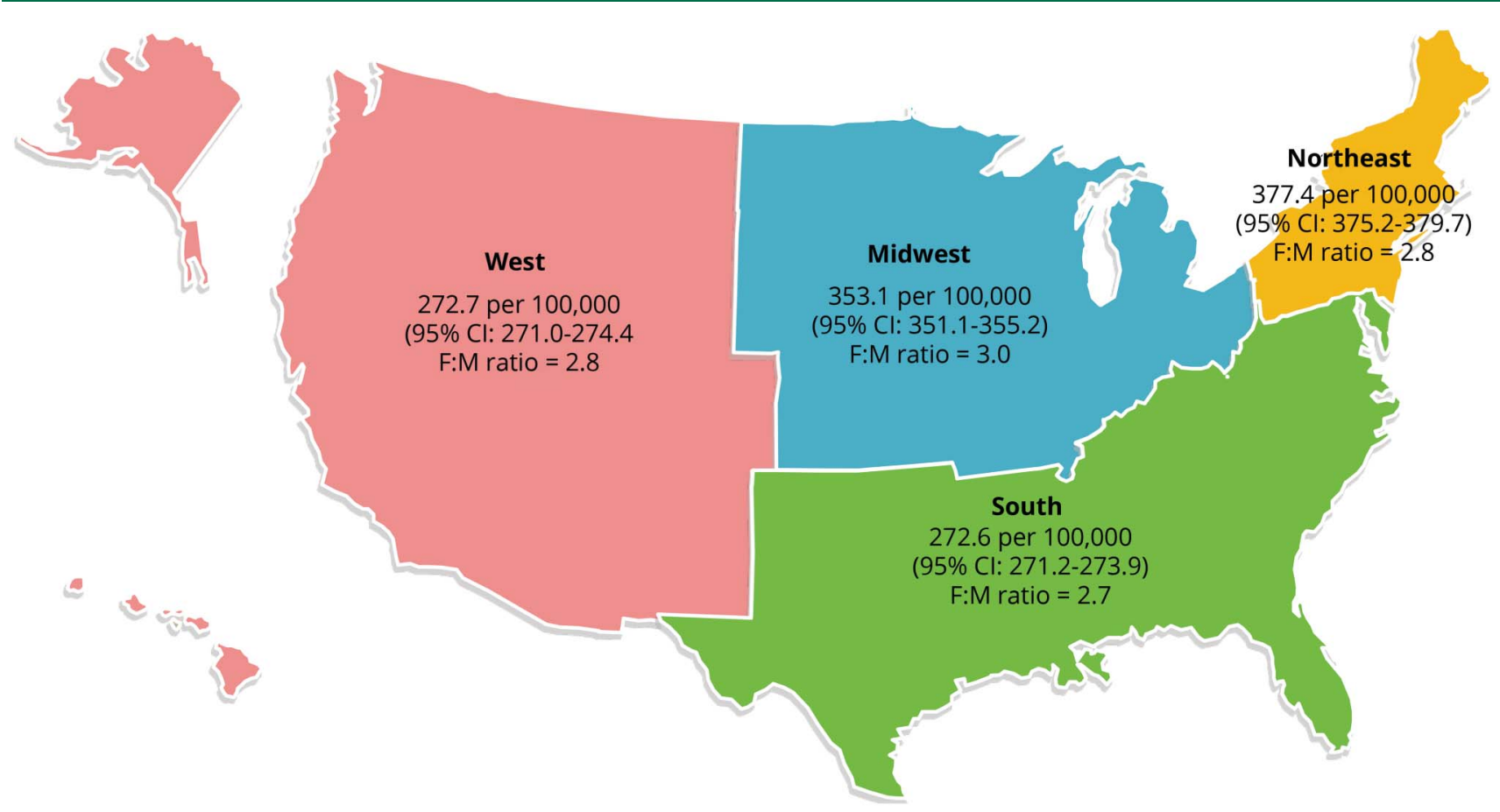

$\mathrm{Cl}$ = confidence interval; F:M = female:male; $\mathrm{MS}$ = multiple sclerosis .

100,000 in the province of British Columbia in $2008 .^{8}$ In European regions, the prevalence of MS has been variable, with northern regions having higher estimates. For example, a 2005 national prevalence of 154.5 per 100,000 (European Standard Population) was reported from Denmark. ${ }^{24}$ Over the past decade, France has had national prevalence estimates generally $<94.7$ per 100,000 (standardized to French population). ${ }^{25}$ South American prevalence studies are largely regional, but a 2005 study from Panama produced a crude prevalence of 5.2 per $100,000,{ }^{26}$ substantially lower than North American estimates.

Prevalence is the product of the incidence rate and the average duration of a condition. Incidence rates for MS have been generally stable or have slightly increased over the past 4 to 5 decades in white populations but are higher in selected racial groups. ${ }^{27-29}$ Therefore, the rising prevalence estimates for MS across the Western world (i.e., populations of predominately European ancestry) largely reflect the aging of the population with improved survival. ${ }^{7}$ In addition, the diagnostic criteria for MS have evolved, and an earlier diagnosis of MS is possible with the use of neuroimaging, and this is likely contributing to the increased prevalence observed. ${ }^{30,31}$

With the wide availability of electronic datasets within health care systems and new techniques to analyze data, there has been a rise in the number of morbidity and mortality studies on a global scale. ${ }^{3}$ However, the methods for identifying cases and other variables of interest have not been standardized. To ensure that our approach is transparent and to support comparisons to future work in the United States and other jurisdictions, we have reported the annual MS prevalence rates for our combined and individual datasets.

A strength of our study is the validation of our algorithm against an available gold standard, that is, medical records in multiple datasets and health systems. ${ }^{13}$ Our approach also accounted for the complexity of the current national health care system. ${ }^{1}$ To address the need for accurate morbidity and mortality data for neurologic conditions, a national surveillance system approach compiling electronic AHC datasets and vital statistics would be a logical way forward. The Neurological Disease Surveillance System that was authorized by the US Congress in 2016 could adopt this relatively time- and cost-efficient approach. ${ }^{32}$

On the basis of observed increases in prevalence with our VA and Intercontinental Marketing Services datasets after 2010, we estimated that the prevalence of MS in 2017 cumulated over 17 years would range from 337.9 per 100,000 population ( $\mathrm{n}=851,749$ persons with MS) to 362.6 per 100,000 population ( $\mathrm{n}=913,925$ persons with MS). These 17 -year cumulative estimates approach lifetime prevalence for MS within the bounds of our AHC datasets. However, these estimates should be viewed with caution because they assume that the factors that have contributed to the rising prevalence observed in the United States as of 2010 based on coding records have persisted to 2017 and that substantial changes in 
Table 22010 Prevalence for MS cumulated over 10 years in the United States per 100,000 population by age, sex, and geography

\begin{tabular}{|c|c|c|c|c|c|c|c|c|c|}
\hline \multirow[b]{2}{*}{$\begin{array}{l}\text { Age and sex } \\
\text { groups (y) }\end{array}$} & \multicolumn{2}{|l|}{ West } & \multicolumn{2}{|c|}{ Midwest } & \multicolumn{2}{|c|}{ Northeast } & \multicolumn{2}{|l|}{ South } & \multirow{2}{*}{$\begin{array}{l}\text { Total } \\
\text { Prevalence } \\
(95 \% \mathrm{Cl})\end{array}$} \\
\hline & $\begin{array}{l}\text { Cases, } \\
\mathrm{n}\end{array}$ & $\begin{array}{l}\text { Prevalence } \\
(95 \% \mathrm{CI})\end{array}$ & $\begin{array}{l}\text { Cases, } \\
\text { n }\end{array}$ & $\begin{array}{l}\text { Prevalence } \\
(95 \% \mathrm{Cl})\end{array}$ & $\begin{array}{l}\text { Cases, } \\
\text { n }\end{array}$ & $\begin{array}{l}\text { Prevalence } \\
(95 \% \mathrm{Cl})\end{array}$ & $\begin{array}{l}\text { Cases, } \\
\mathrm{n}\end{array}$ & $\begin{array}{l}\text { Prevalence } \\
(95 \% \mathrm{Cl})\end{array}$ & \\
\hline Women 18-24 & 1,276 & $\begin{array}{l}36.0 \\
(33.6-38.4)\end{array}$ & 1,506 & $\begin{array}{l}46.8 \\
(44.0-49.6)\end{array}$ & 1,716 & $\begin{array}{l}63.9 \\
(60.3-67.5)\end{array}$ & 2,652 & $\begin{array}{l}47.1 \\
(45.0-49.3)\end{array}$ & $\begin{array}{l}47.4 \\
(46.1-48.8)\end{array}$ \\
\hline Men 18-24 & 759 & $\begin{array}{l}19.8 \\
(18.2-21.5)\end{array}$ & 599 & $\begin{array}{l}17.9 \\
(16.2-19.7)\end{array}$ & 832 & $\begin{array}{l}30.1 \\
(27.6-32.5)\end{array}$ & 1,123 & $\begin{array}{l}19.2 \\
(17.8-20.5)\end{array}$ & $\begin{array}{l}21.0 \\
(20.1-21.8)\end{array}$ \\
\hline Women 25-34 & 8,921 & $\begin{array}{l}179.4 \\
(174.9-183.8)\end{array}$ & 10,254 & $\begin{array}{l}241.0 \\
(235.4-246.6)\end{array}$ & 9,130 & $\begin{array}{l}258.3 \\
(252.0-264.7)\end{array}$ & 14,769 & $\begin{array}{l}193.6 \\
(189.8-197.3)\end{array}$ & $\begin{array}{l}211.2 \\
(208.8-213.6)\end{array}$ \\
\hline Men 25-34 & 2,935 & $\begin{array}{l}56.8 \\
(54.3-59.2)\end{array}$ & 3,442 & $\begin{array}{l}80.0 \\
(76.8-83.3)\end{array}$ & 3,548 & $\begin{array}{l}102.0 \\
(97.9-106.0)\end{array}$ & 5,618 & $\begin{array}{l}74.5 \\
(72.1-76.8)\end{array}$ & $\begin{array}{l}75.8 \\
(74.4-77.3)\end{array}$ \\
\hline Women 35-44 & 17,235 & $\begin{array}{l}356.0 \\
(349.7-362.4)\end{array}$ & 23,328 & $\begin{array}{l}537.7 \\
(529.4-546.0)\end{array}$ & 20,554 & $\begin{array}{l}543.1 \\
(534.2-552.0)\end{array}$ & 33,574 & $\begin{array}{l}428.6 \\
(423.1-434.1)\end{array}$ & $\begin{array}{l}455.3 \\
(451.8-458.8)\end{array}$ \\
\hline Men 35-44 & 6,254 & $\begin{array}{l}126.7 \\
(122.9-130.5)\end{array}$ & 7,476 & $\begin{array}{l}174.1 \\
(169.4-178.9)\end{array}$ & 6,834 & $\begin{array}{l}187.8 \\
(182.5-193.1)\end{array}$ & 10,473 & $\begin{array}{l}136.4 \\
(133.3-139.5)\end{array}$ & $\begin{array}{l}151.0 \\
(149.1-153.1)\end{array}$ \\
\hline Women 45-54 & 28,460 & $\begin{array}{l}561.2 \\
(553.3-569.0)\end{array}$ & 35,392 & $\begin{array}{l}705.2 \\
(696.4-714.0)\end{array}$ & 33,093 & $\begin{array}{l}762.3 \\
(752.5-772.2)\end{array}$ & 47,026 & $\begin{array}{l}561.2 \\
(555.1-567.3)\end{array}$ & $\begin{array}{l}631.2 \\
(627.3-635.1)\end{array}$ \\
\hline Men 45-54 & 8,765 & $\begin{array}{l}175.0 \\
(170.6-179.4)\end{array}$ & 11,889 & $\begin{array}{l}240.9 \\
(235.7-246.1)\end{array}$ & 10,775 & $\begin{array}{l}260.5 \\
(254.6-266.4)\end{array}$ & 14,107 & $\begin{array}{l}175.6 \\
(172.1-179.1)\end{array}$ & $\begin{array}{l}205.9 \\
(203.6-208.2)\end{array}$ \\
\hline Women 55-64 & 27,055 & $\begin{array}{l}640.1 \\
(630.9-649.2)\end{array}$ & 31,080 & $\begin{array}{l}745.1 \\
(735.2-755.0)\end{array}$ & 26,874 & $\begin{array}{l}752.2 \\
(741.4-763.0)\end{array}$ & 39,796 & $\begin{array}{l}564.0 \\
(557.4-570.6)\end{array}$ & $\begin{array}{l}656.0 \\
(651.6-660.3)\end{array}$ \\
\hline Men 55-64 & 9,964 & $\begin{array}{l}248.8 \\
(242.9-254.6)\end{array}$ & 11,753 & $\begin{array}{l}295.5 \\
(289.1-301.9)\end{array}$ & 10,018 & $\begin{array}{l}304.8 \\
(297.6-311.9)\end{array}$ & 12,451 & $\begin{array}{l}193.2 \\
(189.1-197.2)\end{array}$ & $\begin{array}{l}249.4 \\
(246.6-252.2)\end{array}$ \\
\hline Women 65-74 & 14,304 & $\begin{array}{l}573.1 \\
(561.8-584.3)\end{array}$ & 17,410 & $\begin{array}{l}684.9 \\
(672.8-697.1)\end{array}$ & 15,373 & $\begin{array}{l}703.6 \\
(690.2-716.9)\end{array}$ & 23,247 & $\begin{array}{l}517.8 \\
(509.8-525.7)\end{array}$ & $\begin{array}{l}600.5 \\
(595.2-605.8)\end{array}$ \\
\hline Men 65-74 & 5,376 & $\begin{array}{l}241.2 \\
(233.5-248.9)\end{array}$ & 5,972 & $\begin{array}{l}270.2 \\
(262.0-278.4)\end{array}$ & 4,867 & $\begin{array}{l}265.4 \\
(256.5-274.4)\end{array}$ & 7,232 & $\begin{array}{l}186.0 \\
(180.9-191.2)\end{array}$ & $\begin{array}{l}230.8 \\
(227.2-234.3)\end{array}$ \\
\hline Women $\geq 75$ & 4,685 & $\begin{array}{l}204.7 \\
(197.7-211.7)\end{array}$ & 5,838 & $\begin{array}{l}220.8 \\
(214.0-227.6)\end{array}$ & 6,565 & $\begin{array}{l}276.9 \\
(268.9-285.0)\end{array}$ & 6,987 & $\begin{array}{l}174.6 \\
(169.7-179.5)\end{array}$ & $\begin{array}{l}213.0 \\
(209.7-216.2)\end{array}$ \\
\hline Men $\geq 75$ & 1,749 & $\begin{array}{l}110.4 \\
(104.2-116.6)\end{array}$ & 1,583 & $\begin{array}{l}95.6 \\
(89.9-101.2)\end{array}$ & 1,288 & $\begin{array}{l}89.4 \\
(83.6-95.3)\end{array}$ & 2,084 & $\begin{array}{l}80.5 \\
(76.3-84.6)\end{array}$ & $\begin{array}{l}92.2 \\
(89.6-94.9)\end{array}$ \\
\hline Total & 137,734 & $\begin{array}{l}254.1 \\
(252.5-255.7)\end{array}$ & 167,521 & $\begin{array}{l}329.1 \\
(327.2-331.0)\end{array}$ & 151,467 & $\begin{array}{l}351.8 \\
(349.6-353.9)\end{array}$ & 221,138 & $\begin{array}{l}254.0 \\
(252.7-255.3)\end{array}$ & $\begin{array}{l}288.2 \\
(287.4-289.0)\end{array}$ \\
\hline
\end{tabular}

Abbreviations: $\mathrm{Cl}=$ confidence interval; $\mathrm{MS}=$ multiple sclerosis.

Lower estimates adjusted to 2010 US Census on the basis of combined datasets from the MS algorithm inclusive of the following: Truven, Optum, Department of Veterans Affairs, Medicare, and Medicaid.

the distribution and survival of the population at risk of MS have not occurred. These assumptions include the continued high longevity of patients with MS and the general population, stable incidence of MS, and similar coding practices from 2010 to 2017. Extrapolated estimates have been modeled for MS and systemic lupus erythematosus within the Canadian health care system ${ }^{17,33}$ by assuming stable incidence, which has been consistently reported across Canada. In the United States, recent data from the Centers for Disease Control and Prevention show a slight decrease in life expectancy for the US population in 2016, ${ }^{34}$ and the demographic composition of the US population is also changing. ${ }^{35}$ Future studies can use these methods to reassess the prevalence of MS and to examine how these factors affect the findings.
There are limitations to our approach. First, we did not include children, the Indian Health Service, the US prison system, or undocumented US residents in our prevalence estimates. However, these segments of the population are relatively small or, in the case of children, would contribute few cases, and many individuals would be detected by other health systems, including the Medicare insurance program, at some point later in life. Furthermore, diagnosing pediatric MS is challenging; the performance of our proposed algorithm would need to be tested in this population given the recognized differences in relapse rates, more prominent cognitive impairment that may affect health care use, and reported differences in performance of algorithms across the pediatric and adult populations in other chronic diseases. ${ }^{36-38}$ This 
Table 32010 Prevalence for MS cumulated over 10 years in the United States per 100,000 population by age, sex and geography

\begin{tabular}{|c|c|c|c|c|c|c|c|c|c|}
\hline \multirow[b]{2}{*}{$\begin{array}{l}\text { Age and sex } \\
\text { groups (y) }\end{array}$} & \multicolumn{2}{|l|}{ West } & \multicolumn{2}{|l|}{ Midwest } & \multicolumn{2}{|c|}{ Northeast } & \multicolumn{2}{|l|}{ South } & \multirow{2}{*}{$\begin{array}{l}\text { Total } \\
\text { Prevalence } \\
(95 \% \mathrm{Cl})\end{array}$} \\
\hline & $\begin{array}{l}\text { Cases, } \\
\mathrm{n}\end{array}$ & $\begin{array}{l}\text { Prevalence } \\
(95 \% \mathrm{CI})\end{array}$ & $\begin{array}{l}\text { Cases, } \\
\text { n }\end{array}$ & $\begin{array}{l}\text { Prevalence } \\
(95 \% \mathrm{CI})\end{array}$ & $\begin{array}{l}\text { Cases, } \\
\text { n }\end{array}$ & $\begin{array}{l}\text { Prevalence } \\
(95 \% \mathrm{CI})\end{array}$ & $\begin{array}{l}\text { Cases, } \\
\mathrm{n}\end{array}$ & $\begin{array}{l}\text { Prevalence } \\
(95 \% \mathrm{Cl})\end{array}$ & \\
\hline Women 18-24 & 1,369 & $\begin{array}{l}38.6 \\
(36.1-41.2)\end{array}$ & 1,616 & $\begin{array}{l}50.2 \\
(47.2-53.3)\end{array}$ & 1,841 & $\begin{array}{l}68.6 \\
(64.7-72.5)\end{array}$ & 2,846 & $\begin{array}{l}50.6 \\
(48.2-52.9)\end{array}$ & $\begin{array}{l}50.9 \\
(49.5-52.3)\end{array}$ \\
\hline Men 18-24 & 814 & $\begin{array}{l}21.3 \\
(19.5-23.1)\end{array}$ & 642 & $\begin{array}{l}19.2 \\
(17.4-21.1)\end{array}$ & 893 & $\begin{array}{l}32.3 \\
(29.6-34.9)\end{array}$ & 1,205 & $\begin{array}{l}20.6 \\
(19.1-22.0)\end{array}$ & $\begin{array}{l}22.5 \\
(21.6-23.4)\end{array}$ \\
\hline Women 25-34 & 9,572 & $\begin{array}{l}192.5 \\
(187.7-197.3)\end{array}$ & 11,003 & $\begin{array}{l}258.6 \\
(252.6-264.6)\end{array}$ & 9,796 & $\begin{array}{l}277.2 \\
(207.4-294.0)\end{array}$ & 15,846 & $\begin{array}{l}207.7 \\
(203.7-211.7)\end{array}$ & $\begin{array}{l}226.7 \\
(224.1-229.2)\end{array}$ \\
\hline Men 25-34 & 3,149 & $\begin{array}{l}60.9 \\
(58.2-63.5)\end{array}$ & 3,694 & $\begin{array}{l}85.9 \\
(82.4-89.3)\end{array}$ & 3,807 & $\begin{array}{l}109.4 \\
(105.1-113.7)\end{array}$ & 6,029 & $\begin{array}{l}79.9 \\
(77.4-82.4)\end{array}$ & $\begin{array}{l}81.4 \\
(79.8-82.9)\end{array}$ \\
\hline Women 35-44 & 18,493 & $\begin{array}{l}382.0 \\
(375.2-388.9)\end{array}$ & 25,030 & $\begin{array}{l}577.0 \\
(568.1-585.8)\end{array}$ & 22,055 & $\begin{array}{l}582.7 \\
(573.2-592.2)\end{array}$ & 36,024 & $\begin{array}{l}459.9 \\
(454.0-465.8)\end{array}$ & $\begin{array}{l}488.5 \\
(484.8-492.3)\end{array}$ \\
\hline Men 35-44 & 6,711 & $\begin{array}{l}136.0 \\
(131.9-140.0)\end{array}$ & 8,022 & $\begin{array}{l}186.9 \\
(181.8-191.9)\end{array}$ & 7,333 & $\begin{array}{l}201.5 \\
(195.8-207.2)\end{array}$ & 11,237 & $\begin{array}{l}146.4 \\
(143.0-149.7)\end{array}$ & $\begin{array}{l}162.1 \\
(159.9-164.3)\end{array}$ \\
\hline Women 45-54 & 30,537 & $\begin{array}{l}602.1 \\
(593.7-610.5)\end{array}$ & 37,975 & $\begin{array}{l}736.7 \\
(747.3-766.2)\end{array}$ & 35,509 & $\begin{array}{l}818.0 \\
(807.4-828.5)\end{array}$ & 50,458 & $\begin{array}{l}602.2 \\
(595.7-608.7)\end{array}$ & $\begin{array}{l}677.2 \\
(673.0-681.4)\end{array}$ \\
\hline Men 45-54 & 9,404 & $\begin{array}{l}187.8 \\
(183.1-192.5)\end{array}$ & 12,756 & $\begin{array}{l}258.4 \\
(252.9-264.0)\end{array}$ & 11,562 & $\begin{array}{l}279.5 \\
(273.2-285.8)\end{array}$ & 15,136 & $\begin{array}{l}188.4 \\
(184.7-192.1)\end{array}$ & $\begin{array}{l}220.9 \\
(218.5-223.4)\end{array}$ \\
\hline Women 55-64 & 29,030 & $\begin{array}{l}686.8 \\
(677.0-696.6)\end{array}$ & 33,349 & $\begin{array}{l}800.0 \\
(788.8-810.1)\end{array}$ & 28,835 & $\begin{array}{l}807.1 \\
(795.5-818.7)\end{array}$ & 42,701 & $\begin{array}{l}605.2 \\
(598.0-612.3)\end{array}$ & $\begin{array}{l}703.8 \\
(699.1-708.5)\end{array}$ \\
\hline Men 55-64 & 10,691 & $\begin{array}{l}266.9 \\
(260.7-273.2)\end{array}$ & 12,611 & $\begin{array}{l}317.0 \\
(310.2-323.9)\end{array}$ & 10,750 & $\begin{array}{l}327.0 \\
(319.3-334.7)\end{array}$ & 13,360 & $\begin{array}{l}207.3 \\
(202.9-211.6)\end{array}$ & $\begin{array}{l}267.6 \\
(264.6-270.6)\end{array}$ \\
\hline Women 65-74 & 15,349 & $\begin{array}{l}614.9 \\
(602.8-627.0)\end{array}$ & 18,680 & $\begin{array}{l}734.9 \\
(721.9-748.0)\end{array}$ & 16,495 & $\begin{array}{l}754.9 \\
(740.6-769.2)\end{array}$ & 24,945 & $\begin{array}{l}555.6 \\
(547.0-564.1)\end{array}$ & $\begin{array}{l}644.3 \\
(638.6-650.0)\end{array}$ \\
\hline Men 65-74 & 5,769 & $\begin{array}{l}258.8 \\
(250.5-267.1)\end{array}$ & 6,408 & $\begin{array}{l}290.0 \\
(281.1-298.8)\end{array}$ & 5,222 & $\begin{array}{l}284.8 \\
(275.2-294.4)\end{array}$ & 7,760 & $\begin{array}{l}199.6 \\
(194.1-205.1)\end{array}$ & $\begin{array}{l}247.6 \\
(243.8-251.4)\end{array}$ \\
\hline Women $\geq 75$ & 5,027 & $\begin{array}{l}219.6 \\
(212.1-227.2)\end{array}$ & 6,264 & $\begin{array}{l}236.9 \\
(229.6-244.2)\end{array}$ & 7,043 & $\begin{array}{l}297.2 \\
(288.5-305.8)\end{array}$ & 7,497 & $\begin{array}{l}187.3 \\
(182.1-192.6)\end{array}$ & $\begin{array}{l}228.5 \\
(225.0-232.0)\end{array}$ \\
\hline Men $\geq 75$ & 1,877 & $\begin{array}{l}118.5 \\
(111.8-125.1)\end{array}$ & 1,699 & $\begin{array}{l}102.6 \\
(96.5-108.6)\end{array}$ & 1,382 & $\begin{array}{l}95.9 \\
(89.7-102.2)\end{array}$ & 2,236 & $\begin{array}{l}86.4 \\
(81.9-90.8)\end{array}$ & $\begin{array}{l}98.9 \\
(96.1-101.8)\end{array}$ \\
\hline Total & 147,792 & $\begin{array}{l}272.7 \\
(271.0-274.4)\end{array}$ & 179,749 & $\begin{array}{l}353.1 \\
(351-355.2)\end{array}$ & 162,523 & $\begin{array}{l}377.4 \\
(375.2-379.7)\end{array}$ & 237,279 & $\begin{array}{l}272.6 \\
(272.2-274.0)\end{array}$ & $\begin{array}{l}309.2 \\
(308.3-310.1)\end{array}$ \\
\hline
\end{tabular}

Abbreviations: $\mathrm{Cl}=$ confidence interval; $\mathrm{MS}=$ multiple sclerosis.

Higher estimates adjusted to 2010 US Census on the basis of combined datasets from the MS algorithm inclusive of the following: Truven, Optum, Department of Veterans Affairs, Medicare, and Medicaid.

work was out of the scope of the present project but should be pursued in future studies. Second, those with MS not followed in the traditional health care system (e.g., alternative medicine or cash health care practices that bypass health insurance reimbursement) would be missed by our method. This would result in an underestimate of MS cases. Third, we had 10 years of data for the VA health care system and the province of Manitoba but shorter lengths of data for other health systems to assess period effects on prevalence. While a decade of data would have been optimal for all health system datasets, the high costs of obtaining $>3$ years of data for all insurance pools were prohibitive. Finally, we have not characterized the racial or ethnic demographics of our MS population in this report because race and ethnicity were not uniformly collected in the
AHC datasets used. Racial and ethnic differences in MS susceptibility may be a factor contributing to the geographic differences in prevalence in US Census regions. ${ }^{28}$ Strengths of our approach included the large sample, which captured onethird of the US population; broad healthcare system representation; and the use of a validated case-finding algorithm that performed consistently across different health systems. ${ }^{13}$

The US national MS prevalence estimate for 2010 is the highest reported to date and provides a contemporary understanding of the disease burden. Our rigorous algorithmbased approach to estimate prevalence is efficient and can be reproduced in other health systems. We would advocate for this approach to be used for other chronic neurologic 
conditions. Further work is needed to better understand the current differences in MS prevalence by race and to evaluate possible regional differences in health care use and disease morbidity for MS.

\section{Acknowledgment}

The authors thank the following coinvestigators and members of US Multiple Sclerosis Prevalence Workgroup for their contributions: Albert Lo, Robert McBurney, Oleg Muravov, Bari Talente, and Leslie Ritter. The authors also thank the following key staff members at the NMSS as contributors to this project: Cathy Carlson, Timothy Coetzee, Sherri Giger, Weyman Johnson, Eileen Madray, Graham McReynolds, and Cyndi Zagieboylo.

\section{Study funding}

This study was funded by a grant from the NMSS (HC-150805693).

\section{Disclosure}

M. Wallin has served on data safety monitoring boards for the National Institutes of Neurological Disease and Stroke-NIH, is a member of the NMSS Health Care Delivery and Policy Research study section, and receives funding support from the NMSS and the Department of Veterans Affairs Merit Review Research Program. W. Culpepper has research funding from the NMSS, receives support from the VHA MS Center of Excellence, and is a member of the NMSS Health Care Delivery and Policy Research study section. J. Campbell has consultancy or research grants over the past 5 years from the Agency for Healthcare Research and Quality, ALSAM Foundation, Amgen, AstraZeneca, Bayer, Biogen Idec, Boehringer Ingelheim, Centers for Disease Control and Prevention, Colorado Medicaid, Enterprise Community Partners Inc, Institute for Clinical and Economic Review, Mallinckrodt, NIH, NMSS, Kaiser Permanente, PhRMA Foundation, Teva, Research in Real Life Ltd, Respiratory

\section{Appendix 1 Authors}

\begin{tabular}{|c|c|c|c|}
\hline Name & Location & Role & Contribution \\
\hline $\begin{array}{l}\text { Mitchell T. Wallin, } \\
\text { MD, MPH }\end{array}$ & $\begin{array}{l}\text { Department of Veterans Affairs Medical Center; } \\
\text { Georgetown University, Washington, DC }\end{array}$ & Author & $\begin{array}{l}\text { Study concept and design, critical review, statistical analyses, } \\
\text { revision of the manuscript for content, approval of final } \\
\text { manuscript }\end{array}$ \\
\hline $\begin{array}{l}\text { William J. Culpepper, } \\
\text { PhD }\end{array}$ & $\begin{array}{l}\text { Department of Veterans Affairs Medical Center, } \\
\text { Washington, DC; University of Maryland, Baltimore, M } \\
\text { D }\end{array}$ & Author & $\begin{array}{l}\text { Study concept and design, statistical analyses, critical review, } \\
\text { preparation of draft manuscript, approval of final } \\
\text { manuscript }\end{array}$ \\
\hline $\begin{array}{l}\text { Jonathan Campbell, } \\
\text { PhD }\end{array}$ & University of Colorado, Denver, CO & Author & $\begin{array}{l}\text { Statistical analyses, critical review of the manuscript for } \\
\text { content, approval of final manuscript }\end{array}$ \\
\hline $\begin{array}{l}\text { Lorene M. Nelson, } \\
\text { PhD }\end{array}$ & Stanford University, Stanford, CA & Author & $\begin{array}{l}\text { Study concept and design, critical review, revision of the } \\
\text { manuscript for content, approval of final manuscript }\end{array}$ \\
\hline $\begin{array}{l}\text { Annette Langer- } \\
\text { Gould, MD }\end{array}$ & $\begin{array}{l}\text { Kaiser Permanente Southern California, Los Angeles, } \\
\text { CA }\end{array}$ & Author & $\begin{array}{l}\text { Study concept and design, statistical analyses, critical review, } \\
\text { revision of the manuscript for content, approval of final } \\
\text { manuscript }\end{array}$ \\
\hline $\begin{array}{l}\text { Ruth Ann Marrie, } \\
\text { MD, PhD }\end{array}$ & University of Manitoba, Winnipeg, Manitoba, Canada & Author & $\begin{array}{l}\text { Study concept and design, critical review, revision of the } \\
\text { manuscript for content, approval of final manuscript }\end{array}$ \\
\hline Gary R. Cutter, PhD & University of Alabama, Birmingham & Author & $\begin{array}{l}\text { Statistical analyses, study concept and design, revision of the } \\
\text { manuscript for content, approval of final manuscript }\end{array}$ \\
\hline Wendy Kaye, PhD & McKing Consulting Corp, Atlanta, GA & Author & $\begin{array}{l}\text { Statistical analyses, critical review of the manuscript for } \\
\text { content }\end{array}$ \\
\hline Laurie Wagner, MPH & McKing Consulting Corp, Atlanta, GA & Author & $\begin{array}{l}\text { Statistical analyses, critical review of the manuscript for } \\
\text { content }\end{array}$ \\
\hline Helen Tremlett, PhD & University of British Columbia, Vancouver, BC, Canada & Author & $\begin{array}{l}\text { Study concept and design, critical review of the manuscript } \\
\text { for content, approval of final manuscript }\end{array}$ \\
\hline Steven L. Buka, ScD & Brown University, Providence, RI & Author & $\begin{array}{l}\text { Critical review of the manuscript for content, approval of final } \\
\text { manuscript }\end{array}$ \\
\hline $\begin{array}{l}\text { Piyameth } \\
\text { Dilokthornsakul, } \\
\text { PharmD, PhD }\end{array}$ & University of Colorado, Aurora, CO & Author & $\begin{array}{l}\text { Statistical analysis, critical review of the manuscript for } \\
\text { content }\end{array}$ \\
\hline Barbara Topol, MS & Stanford University, Stanford, CA & Author & $\begin{array}{l}\text { Statistical analysis, critical review of the manuscript for } \\
\text { content }\end{array}$ \\
\hline Lie H. Chen, DrPH & $\begin{array}{l}\text { Southern California Permanente Medical Group, } \\
\text { Pasadena, CA }\end{array}$ & Author & $\begin{array}{l}\text { Statistical analysis, critical review of the manuscript for } \\
\text { content }\end{array}$ \\
\hline Nicholas G. LaRocca & National Multiple Sclerosis Society, New York, NY & Author & $\begin{array}{l}\text { Study concept and design, critical review of the manuscript } \\
\text { for content, approval of final manuscript }\end{array}$ \\
\hline
\end{tabular}


Appendix 2 Coinvestigators and members of the US Multiple Sclerosis Prevalence Workgroup

\begin{tabular}{|c|c|c|c|}
\hline Name & Location & Role & Contribution \\
\hline Albert Lo, MD, PhD & Brown University, Providence, RI & Coinvestigator & $\begin{array}{l}\text { Study concept and } \\
\text { design }\end{array}$ \\
\hline $\begin{array}{l}\text { Robert McBurney, } \\
\text { PhD }\end{array}$ & Accelerated Cure Project, Boston, MA & Coinvestigator & $\begin{array}{l}\text { Study concept and } \\
\text { design }\end{array}$ \\
\hline Oleg Muravov, PhD & $\begin{array}{l}\text { Agency for Toxic Substances and Disease Registry Division of Health Studies, } \\
\text { Atlanta, GA }\end{array}$ & Coinvestigator & $\begin{array}{l}\text { Study concept and } \\
\text { design }\end{array}$ \\
\hline Bari Talente, Esq & National Multiple Sclerosis Society, Washington, DC & Coinvestigator & $\begin{array}{l}\text { Study concept and } \\
\text { design }\end{array}$ \\
\hline Leslie Ritter & National Multiple Sclerosis Society, Washington, DC & Coinvestigator & $\begin{array}{l}\text { Study concept and } \\
\text { design }\end{array}$ \\
\hline
\end{tabular}

Effectiveness Group, and Zogenix Inc. L. Nelson receives grants from the Centers for Disease Control and Prevention, NIH, and NMSS and contracts from the Agency for Toxic Substances and Diseases Registry. She receives compensation for serving as a consultant to Acumen, Inc and is on the Data Monitoring Committee of Neuropace. A. Langer-Gould was site principal investigator for 2 industry-sponsored phase 3 clinical trials (Biogen Idec and Hoffman-LaRoche) and 1 industry-sponsored observation study (Biogen Idec). She receives grant support from the NIH, National Institutes of Neurological Disease and Stroke, Patient-Centered Outcomes Research Institute, and the NMSS. R. Marrie is supported by the Waugh Family Chair in Multiple Sclerosis and receives research funding from Canadian Institutes of Health Research, Research Manitoba, Multiple Sclerosis Society of Canada, Multiple Sclerosis Scientific Foundation, Consortium of MS Centers, and NMSS. She also serves on the Editorial Board of Neurology. G. Cutter is a member of Data and Safety Monitoring Boards for AMO Pharmaceuticals, Apotek, Horizon Pharmaceuticals, Modigenetech/Prolor, Merck, Merck/Pfizer, Opko Biologics, Neurim, Sanofi-Aventis, Reata Pharmaceuticals, Receptos/Celgene, Teva Pharmaceuticals, National Heart, Lung, and Blood Institute (Protocol Review Committee), and National Institute of Child Health and Human Development (Obstetric Pharmacy Research Unit oversight committee) and on the Consulting or Advisory boards for Atara Biotherapeutics, Argenix, Bioeq GmBH, Consortium of MS Centers (grant), Genzyme, Genentech, Innate Therapeutics, Klein-Buendel Inc, Medimmune, Medday, Novartis, Opexa Therapeutics, Roche, Savara Inc, Somahlution, Teva Pharmaceuticals, Transparency Life Sciences, and TG Therapeutics. W. Kaye receives funding from the Agency for Toxic Substances and Disease Registry, the NMSS, and the Association for the Accreditation of Human Research Protection Programs. L. Wagner receives funding from the Agency for Toxic Substances and Disease Registry and NMSS. H. Tremlett is the Canada Research Chair for Neuroepidemiology and Multiple Sclerosis. She receives research support from the NMSS, the Canadian Institutes of Health Research, the Multiple Sclerosis Society of Canada, and the Multiple Sclerosis Scientific Research Foundation. In addition, in the last 5 years, she has received research support from the Multiple Sclerosis Society of Canada, the Michael Smith Foundation for Health Research, and the UK MS Trust, as well as travel expenses to attend conferences; all speaker honoraria are either declined or donated to an MS charity or to an unrestricted grant for use by her research group. S. Buka receives research funding from the NIH and the NMSS. P. Dilokthornsakul receives research funding from Pfizer Thailand and the Thai Traditional Medical Knowledge Fund. B. Topol receives grant support from the Centers for Disease Control and Prevention and the NMSS and contracts from the Agency for Toxic Substances and Diseases Registry. L. Chen reports no disclosures relevant to the manuscript. N. LaRocca is employed full-time by the NMSS. Go to Neurology.org/ $\mathrm{N}$ for full disclosures.

\section{Publication history}

Received by Neurology February 24, 2018. Accepted in final form August 17,2018

\section{References}

1. Nelson LM, Wallin MT, Marrie RA, et al. A new way to estimate neurologic disease prevalence in the United States: illustrated with MS. Neurology 2019;92:469-480.

2. Evans C, Beland SG, Kulaga S, et al. Incidence and prevalence of multiple sclerosis in the Americas: a systematic review. Neuroepidemiology 2013;40:195-210.

3. GBD 2015 Neurological Disorders Collaborator Group. Global, regional, and national burden of neurological disorders during 1990-2015: a systematic analysis for the Global Burden of Disease Study 2015. Lancet Neurol 2017;16:877-897.

4. Baum HM, Rothschild BB. The incidence and prevalence of reported multiple sclerosis. Ann Neurol 1981;10:420-428.

5. Anderson DW, Ellenberg JH, Leventhal CM, Reingold SC, Rodrigues M, Silberberg DH. Revised estimate of the prevalence of multiple sclerosis in the United States. Ann Neurol 1992;31:333-336.

6. Mayr WT, Pittock SJ, McClelland RL, Jorgensen NW, Noseworthy JH, Rodrigues M Incidence and prevalence of multiple sclerosis in Olmsted County, Minnesota, 1985-2000. Neurology 2003;61:1373-1377.

7. Marrie RA, Yu N, Blanchard J, Leung S, Elliott L. The rising prevalence and changing age distribution of multiple sclerosis in Manitoba. Neurology 2010;74:464-471.

8. Kingwell E, Zhu F, Marrie RA, et al. High incidence and increasing prevalence of multiple sclerosis in British Columbia, Canada: findings from over two decades (1991-2010). J Neurol 2015;262:2352-2363.

9. Marrie RA, Fisk JD, Stadnyk KJ, et al. The incidence and prevalence of multiple sclerosis in Nova Scotia, Canada. Can J Neurol Sci 2013;40:824-831.

10. US Census Bureau. Annual estimates of the resident population for the United States, 2010-2017. Available at: census.gov/data/datasets/2017/demo/popest/state-total html. Accessed July 14, 2018.

11. US Census Bureau. American community survey. Available at: census.gov/data/ tables/time-series/demo/health-insurance/acs-hi.html. Accessed July 14, 2018.

12. Leonard CE, Brensinger $\mathrm{CM}, \mathrm{Nam} \mathrm{YH}$, et al. The quality of Medicaid and Medicare data obtained from CMS and its contractors: implications for pharmacoepidemiology. BMC Health Serv Res 2017;17:304-311. 
13. Culpepper WJ, Marrie RA, Langer-Gould A, et al. Validation of a Standardized Algorithm for Identifying MS Cases across Claims Datasets. Neurology 2019;92:e1016-e1028.

14. Reich D, Lucchinetti CF, Calabresi PA. Multiple sclerosis. N Engl J Med 2018;378: 169-180.

15. Ruggles S, Genadek K, Goeken R, Grover J, Sobek M. Integrated public use microdata series: version 6.0. Minneapolis: University of Minnesota; 2015. Available at: doi.org/ 10.18128/D010.V6.0. Accessed July 14, 2018

16. Institute of Medicine. Care Without Coverage: Too Little, Too Late. Washington, DC: National Academies Press; 2002. Available at: doi.org/10.17226/10367. Accessed July 14, 2018.

17. Minden SL, Frankel D, Hadden L, Hoaglin DC. Access to health care for people with multiple sclerosis. Mult Scler 2007;13:547-558.

18. $\mathrm{Ng} \mathrm{R}$, Bernatsky S, Rhame E. Observation period effects on estimation of systemic lupus erythematosus incidence and prevalence in Quebec. J Rheumatol 2013;40:1334-1336.

19. Capocaccia R, Colonna M, Corazziari I, et al. Measuring cancer prevalence in Europe: the EUROPREVAL project. Ann Oncol 2002;13:831-839.

20. Noonan CW, Kathman SJ, White MC. Prevalence estimates for MS in the United States and evidence of an increasing trend for women. Neurology 2002;58:136-138.

21. Campbell JD, Ghushchyan V, Brett McQueen R, et al. Burden of multiple sclerosis on direct, indirect costs and quality of life: national US estimates. Mult Scler Relat Disord 2014;3:227-236.

22. Dilokthornsakul P, Valuck RJ, Nair KV, Corboy JR, Allen RR, Campbell JD. Multiple sclerosis prevalence in the United States commercially insured population. Neurology 2016;86:1014-1021.

23. Gray OM, McDonnell GV, Hawkins SA. Factor in the rising prevalence of multiple sclerosis in the north-east of Ireland. Mult Scler 2008;14:880-886.

24. Bentzen J, Flachs EM, Stenager E, Bronnum-Hansen H, Koch-Henriksen N. Prevalence of multiple sclerosis in Denmark 1950-2005. Mult Scler 2010;16:520-525.

25. Kingwell E, Marriott JJ, Gette N, et al. Incidence and prevalence of multiple sclerosis in Europe: a systematic review. BMC Neurol 2013;13:128.
26. Gracia F, Castillo LC, Benazdon A, et al. Prevalence and incidence of multiple sclerosis in Panama (2000-2005). Neuroepidemiology 2009;32:287-293.

27. Koch-Henriksen, Sorensen PS. The changing demographics of multiple sclerosis epidemiology. Lancet Neurol 2010;9:520-532.

28. Langer-Gould A, Brara SM, Beaber BE, Zhang JL. Incidence of multiple sclerosis in multiple racial and ethnic groups. Neurology 2013;80:1734-1739.

29. Wallin MT, Culpepper WJ, Coffman P, et al. The Gulf War era multiple sclerosis cohort: age and incidence rates by race, sex and service. Brain 2012;135:1778-1785.

30. Polman $\mathrm{CH}$, Reingold SC, Banwell B, et al. Diagnostic criteria for multiple sclerosis: 2010 revisions to the McDonald criteria. Ann Neurol 2011;69:292-302.

31. Smith-Bindman R, Miglioretti DL, Larson EB. Rising use of diagnostic medical imaging in a large integrated health system. Health Aff 2008;27:1491-1502.

32. 21st Century Cures Act of 2016. Pub L No. 114-255, section 2061, National Neurological Diseases Surveillance System. 2016.

33. Amankwah N, Marrie RA, Bancej C, et al. Multiple sclerosis in Canada 2011 to 2031: results of a microsimulation modelling study of epidemiological and economic impacts. Health Promot Chronic Dis Prev Can 2017;37:37-48.

34. Kochanek KD, Murphy SL, Xu J, Arias E. Mortality in the United States, 2016. NCHS Data Brief 2017:1-8.

35. Colby SL, Ortman JM. Projections of the Size and Composition of the U.S. Population: 2014 to 2060, Current Population Reports, P25-1143. Washington, DC: US Census Bureau; 2014.

36. Guttmann A, Nakhla M, Henderson M, et al. Validation of a health administrative data algorithm for assessing the epidemiology of diabetes in Canadian children. Pediatr Diabetes 2010;11:122-128.

37. Ghezzi A, Baroncini D, Zaffaroni M, Comi G. Pediatric versus adult MS: similar or different? Mult Scler Demyelin Disord 2017;2:5.

38. Benchimol EI, Guttmann A, Griffiths AM, et al. Increasing incidence of paediatric inflammatory bowel disease in Ontario, Canada: evidence from health administrative data. Gut 2009;58:1490-1497. 


\section{Neurology}

The prevalence of MS in the United States: A population-based estimate using health claims data

Mitchell T. Wallin, William J. Culpepper, Jonathan D. Campbell, et al. Neurology 2019;92;e1029-e1040 Published Online before print February 15, 2019

DOI 10.1212/WNL.0000000000007035

This information is current as of February 15, 2019

Neurology ${ }^{\circledR}$ is the official journal of the American Academy of Neurology. Published continuously since 1951, it is now a weekly with 48 issues per year. Copyright Copyright $@ 2019$ The Author(s). Published by Wolters Kluwer Health, Inc. on behalf of the American Academy of Neurology.. All rights reserved. Print ISSN: 0028-3878. Online ISSN: 1526-632X.

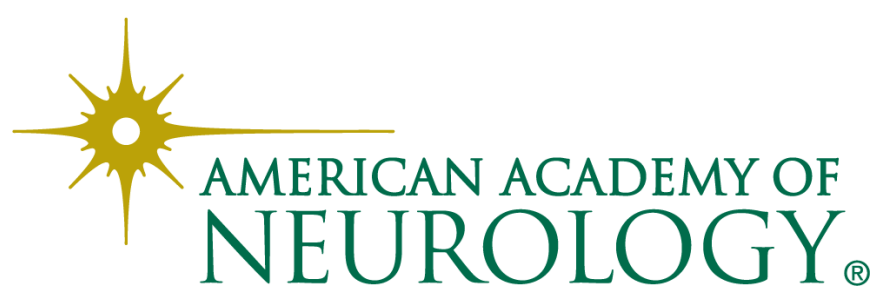




\section{Updated Information \& Services}

References

Citations

Subspecialty Collections

\section{Errata}

\section{Permissions \& Licensing}

\section{Reprints}

including high resolution figures, can be found at: http://n.neurology.org/content/92/10/e1029.full

This article cites 31 articles, 9 of which you can access for free at: http://n.neurology.org/content/92/10/e1029.full\#ref-list-1

This article has been cited by 17 HighWire-hosted articles: http://n.neurology.org/content/92/10/e1029.full\#\#otherarticles

This article, along with others on similar topics, appears in the following collection(s):

All epidemiology

http://n.neurology.org/cgi/collection/all_epidemiology Multiple sclerosis

http://n.neurology.org/cgi/collection/multiple_sclerosis

Prevalence studies

http://n.neurology.org/cgi/collection/prevalence_studies

Screening in epidemiology

http://n.neurology.org/cgi/collection/screening_in_epidemiology

An erratum has been published regarding this article. Please see next page or:

/content/93/15/688.2.full.pdf

Information about reproducing this article in parts (figures,tables) or in its entirety can be found online at:

http://www.neurology.org/about/about_the_journal\#permissions

Information about ordering reprints can be found online:

http://n.neurology.org/subscribers/advertise

Neurology ${ }^{\circledR}$ is the official journal of the American Academy of Neurology. Published continuously since 1951, it is now a weekly with 48 issues per year. Copyright Copyright ( 2019 The Author(s). Published by Wolters Kluwer Health, Inc. on behalf of the American Academy of Neurology.. All rights reserved. Print ISSN: 0028-3878. Online ISSN: 1526-632X.

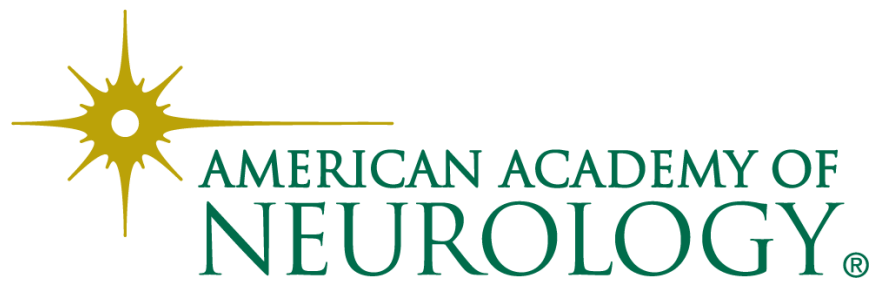




\section{Out-of-pocket costs are on the rise for commonly prescribed neurologic medications}

Neurology ${ }^{\circledR}$ 2019;93:688. doi:10.1212/WNL.0000000000008353

In the article "Out-of-pocket costs are on the rise for commonly prescribed neurologic medications" by Callaghan et al., ${ }^{1}$ first published online May 1, 2019, the 2004 out-of-pocket costs for MS medications (mean [SD]) in the Abstract and Results should be \$33 (\$50) rather than $\$ 15$ (\$23), and the 2004 median/IQR in the Results should be \$25 (\$20-\$32) rather than \$14 (\$10-\$16). The authors regret the errors.

\section{Reference}

1. Callaghan BC, Reynolds E, Banerjee M, et al. Out-of-pocket costs are on the rise for commonly prescribed neurologic medications. Neurology 2019;92:e2604-e2613.

\section{The prevalence of MS in the United States}

A population-based estimate using health claims data Neurology ${ }^{\circledR}$ 2019;93:688. doi:10.1212/WNL.0000000000007915

In the article "The prevalence of MS in the United States: A population-based estimate using health claims data" by Wallin et al., ${ }^{1}$ first published online February 15, 2019, the text regarding the lower bound for MS prevalence in a paragraph in Results should read: "After adjustment for the uninsured and application of the lower-bound inflation factor to account for undercounting due to the limited period of observation, the estimated 2010 prevalence for MS cumulated over 10 years was 288.2 per 100,000 (95\% CI 287.4-289.0), corresponding to 623,437 people with MS." This is correctly represented in table 2 . The authors regret the error.

\section{Reference}

1. Wallin MT, Culpepper WJ, Campbell JD, et al. The prevalence of MS in the United States: a population-based estimate using health claims data. Neurology 2019;92:e1029-e1040.

\section{Epidemiology of NMOSD in Sweden from 1987 to 2013}

A nationwide population-based study

Neurology ${ }^{\circledR}$ 2019;93:688. doi:10.1212/WNL.0000000000008382

In the article "Epidemiology of NMOSD in Sweden from 1987 to 2013: A nationwide population-based study" by Jonsson et al., ${ }^{1}$ in figure 5, the incidence of NMOSD in Australia and New Zealand should have been $0.37 / 1,000,000$ person-years (CI: 0.35-0.39). The figure should also have included A and B labels for the panels and a label for the first panel's x-axis, "Incidence rate (per 1.000.000 individuals)." The authors and the editorial office regret the errors.

\section{Reference}

1. Jonsson DI, Sveinsson O, Hakim R, Brundin L. Epidemiology of NMOSD in Sweden from 1987 to 2013: a nationwide population-based study. Neurology 2019;93:e181-e189. 